\title{
Human Metaplastic Breast Carcinoma and Decorin
}

\author{
Pia Boström ${ }^{1}$ • Annele Sainio ${ }^{2}$ Natalja Eigèlienè $\dot{~}^{3,4} \cdot$ Anne Jokilammi $^{2}$ • \\ Klaus Elenius $^{2,5}$ • Ilkka Koskivuo ${ }^{6}$ Hannu Järveläinen ${ }^{2,7}$ [D
}

Received: 22 December 2016 / Accepted: 16 June 2017 /Published online: 26 June 2017

(C) The Author(s) 2017. This article is an open access publication

\begin{abstract}
Metaplastic breast carcinoma (MBC) is a rare subtype of invasive breast cancer and has poor prognosis. In general, cancers are heterogeneous cellular masses comprised of different cell types and their extracellular matrix (ECM). However, little is known about the composition of the ECM and its constituents in MBC. Decorin is a ubiquitous ECM macromolecule known of its oncosuppressive activity. As such, it provides an intriguing molecule in the development of novel therapeutics for different malignancies such as MBC. In this study, decorin immunoreactivity and the effect of adenoviral decorin cDNA (Ad-DCN) transduction were examined in MBC. Multiple immunohistochemical stainings were used to characterize a massive breast tumour derived from an old woman. Furthermore, three-dimensional (3D) explant
\end{abstract}

Electronic supplementary material The online version of this article (doi:10.1007/s12307-017-0195-8) contains supplementary material, which is available to authorized users.

Hannu Järveläinen

hanjar@utu.fi

1 Department of Pathology, University of Turku and Turku University Hospital, Kiinamyllynkatu 10, 20520 Turku, Finland

2 Department of Medical Biochemistry and Genetics, University of Turku, Kiinamyllynkatu 10, 20520 Turku, Finland

3 Department of Cell Biology and Anatomy, University of Turku, Turku, Finland

4 Oncology Clinic, Vaasa Central Hospital, Vaasa, Hietalahdenkatu 2-4, 65130 Vaasa, Finland

5 Department of Oncology and Radiotherapy, University of Turku and Turku University Hospital, Turku, Finland

6 Department of Plastic and General Surgery, Turku University Hospital, Kiinamyllynkatu 4-8, 20520 Turku, Finland

7 Department of Internal Medicine, Satakunta Central Hospital, Sairaalantie 3, 28500 Pori, Finland cultures derived from the tumour were transduced with AdDCN to study the effect of the transduction on the explants. The MBC tumour was shown to be completely negative for decorin immunoreactivity demonstrating that the malignant cells were not able to synthesize decorin. Ad-DCN transduction resulted in a markedly altered cytological phenotype of MBC explants by decreasing the amount of atypical cells and by inhibiting cell proliferation. The results of this study support approaches to develop new, decorin-based adjuvant therapies for MBC.

Keywords Adenoviral transduction · Decorin · Metaplastic breast carcinoma $\cdot$ Three-dimensional (3D) explant culture

\section{Introduction}

Metaplastic breast carcinoma (MBC) is a rare subtype of invasive breast cancer accounting for $0.2-5 \%$ of all breast malignancies [1]. MBC is a descriptive term and comprises histologically a broad range of invasive breast tumours characterized by co-existence of two or more cellular types. Commonly MBC consists of epithelial (carcinomatous) and mesenchymal (sarcomatous) elements in a variable proportion [2]. MBC is regarded as ductal carcinoma that undergoes metaplasia into squamous cell, spindle cell and/or mesenchymal appearance [3]. Multiple immunohistochemical stainings are required for accurate diagnosis of these tumours because of their various histological patterns. Immunohistochemical analyses have shown that $>90 \%$ of MBCs are negative for estrogen receptor (ER), progesterone receptor (PR) and human epidermal growth factor receptor 2 (HER2/neu), and that they have a consistent expression of basal markers such as cytokeratin 5/6 (CK 5/6) and/or epidermal growth factor receptor (EGFR) [4]. Thus, most MBCs are regarded as a 
subtype of triple negative breast cancer (ER, PR and HER2/ neu negative). For women presenting with triple negative breast cancer, hormonal therapy is generally unsuccessful, albeit initial response to chemotherapy can be good [5]. MBC has also a poor clinicopathological response to local radiotherapy [6]. Subsequently, 5-year overall survival rate of patients with MBC is only $54,5 \%$ [7].

$\mathrm{MBC}$ is usually associated with a lower incidence of axillary nodal involvement compared to typical breast carcinomas of similar size [8]. Nevertheless, MBC tends to have high percentage of local recurrence and distant metastases, particularly in the lung [9]. The different histological subtypes of MBC are associated with distinct clinical behaviour and outcome [10]. Spindle cell and squamous cell subtypes have been shown to associate with a particularly aggressive behaviour [11]. Studies have also shown that MBC may be enriched by primitive cells with stem-like features. This may account for the resistance of the tumour to chemotherapy and enhanced metastatic potential $[12,13]$. Thus, new and novel adjuvant therapies are needed.

In general, cancers are heterogeneous cellular masses comprised of various cell types including malignant cells, immune cells, epithelial cells, stromal cells and their extracellular matrix $(\mathrm{ECM})[14,15]$. Cells in the tumour microenvironment (TME) can be harnessed by malignant cells to possess tumourpromoting function at all stages of tumourigenesis [16-18]. On the other hand, ECM proteins expressed by various stromal cell types can regulate the behaviour of cancer cells and thus affect both cancer progression and metastasis [19-21]. This offers possibilities to target malignant cells, mediators of their communication or macromolecules in the TME to improve the therapeutic prognosis of the disease and to complement other treatment options [22-26].

Certain ECM macromolecules, particularly proteoglycans (PGs) such as decorin, have variously been identified as one of the key players capable of modulating cell signaling, adhesion, migration, proliferation, and apoptosis [27, 28]. Decorin is the prototype member of the small leucine rich proteoglycan (SLRP) gene family [29]. It is capable of interacting with various ECM macromolecules, receptors and growth factors, such as the members of the ErbB family [30-33]. Indeed, decorin is considered as a central modulatory molecule in various types of cancer [34, 35]. Normally, it is expressed by cells of mesenchymal origin such as fibroblasts and vascular smooth muscle cells [36, 37]. In cancers, including breast cancer, the expression of decorin in the TME has been reported to be markedly decreased or totally lacking in malignant cells [38-41]. Reduced level of decorin expression has been shown to be associated with poorer outcome in invasive breast cancer [42], and vice versa, high stromal decorin expression has been indicated to predict better prognosis [43]. Furthermore, decorin adenoviral transduction has been demonstrated to decrease the malignant behaviour of breast cancer cells [40] and even to suppress their capability to form bone metastasis $[44,45]$. As a summary, decorin is currently considered as an oncosuppressive molecule [32, 46, 47]. Interestingly, its close structural relative, biglycan, has been shown to possess opposite function, namely tumourpromoting activity [48-51].

In this case report, a massive breast tumour was first characterized as MBC. Next, the MBC tumour was examined for immunoreactivity for the above two stromal PGs, decorin and biglycan. Thereafter, 3D MBC explant cultures were established and the effect of Ad-DCN transduction on the cytology and proliferation index of the explants was examined. Finally, the effect of Ad-DCN transduction on the expression of the ErbB family members, EGFR (ErbB1), ErbB2 (HER-2, c-Neu), ErbB3 and ErbB4 was also analyzed.

\section{Materials and Methods}

\section{Case Presentation}

We present a case of an 87 years old Finnish woman, who was admitted to Turku University Hospital, Turku, Finland, with a locally advanced breast cancer with ulceration. She was in moderate condition for her years. Her breast examination revealed breast tissue that was red, swollen and had a $3-4 \mathrm{~cm}$ ulceration with cystic cavity. The palpable tumour was over $10 \mathrm{~cm}$ in diameter. The study protocol was approved by the Joint Ethics Committee of the University of Turku and Turku University Hospital, Turku, Finland (number TO6/029/15). Informed consent was obtained from the patient.

\section{Immunohistochemistry}

After radical mastectomy, a representative sample from the fresh breast tumour tissue (BTT) was obtained within half an hour of surgery. The tissue sample was taken from the invasive border of the tumour by a pathologist. Thereafter, the tumour tissue was divided into samples for the immunohistochemistry (IHC) analyses, and samples for the 3D transduction experiments.

The BTT samples for hematoxylin and eosin (HE) staining and IHC were fixed in 10\% neutral-buffered formalin, embedded in paraffin and cut into $4 \mu \mathrm{m}$ consecutive sections. The sections were stained with antibodies against ER (clone SP1; rabbit), PR (clone 1E2; rabbit), HER2 (clone 4B5; rabbit), EGFR (clone 5B7; rabbit), cytokeratin Pan (CkPan, clone AE1/AE3\&PCK26; mouse), cytokeratin 7 (clone SP52; rabbit), p63 (clone 4A4; mouse), CD10 (clone SP67; rabbit), vimentin (clone V9; mouse), epithelial membrane antigen (EMA, clone E29; mouse), CK5/6 (clone D5/16B4; mouse) and Ki-67 (clone 30-9; rabbit) using Ventana Medical Systems/Roche Diagnostics with BenchMark XT 
immunostainer and ultraVIEW Universal DAB Detection Kit (Ventana/Roche; Tucson, Arizona, USA). All the above listed antibodies were ready-to-use dilutions (Diluent 95,119, Ventana/Roche). Antibodies against androgen receptor (AR, clone AR27; dilution 1:10; rabbit) and gross cystic disease fluid protein-15 (GCDFP-15, clone 23A3; dilution 1:10, rabbit) from Novocastra (Leica Biosystems; Newcastle, UK) were also used. The antibodies for AR and GCDFP-15 were diluted in Antibody Diluent from Ventana (251-018, Ventana/Roche).

Additionally, tumour sections were examined for immunoreactivity for decorin (DCN) and biglycan (BGN) [52]. Briefly, incubation with the primary decorin polyclonal rabbit antibody H-80 (dilution 1:50 in blocking buffer) and biglycan polyclonal goat antibody L-15 (dilution 1:50 in blocking buffer) from Santa Cruz Biotechnology (Heidelberg, Germany) were performed overnight at $+4{ }^{\circ} \mathrm{C}$ while control sections were incubated in the blocking buffer, containing $2 \%$ bovine serum albumine (BSA) in phosphate-buffered saline (PBS). Next day, the sections were washed with PBS and incubated for $1 \mathrm{~h}$ with biotinylated secondary antibodies (dilution 1:200 in blocking buffer, Vector Laboratories, Inc., Burlingame). After rinses with PBS, the sections were treated with avidinperoxidase complex solution (Vector Laboratories) for $35 \mathrm{~min}$. Visualization of the signals was achieved with 3,3' diaminobenzidine (Vector Laboratories), and the sections were counter-stained with Papanicolaou hematoxylin and mounted using Aquamount (BDH Laboratory Supplies, Dorset, England). List of all the primary antibodies used in the IHC stainings of the BTT sections can be seen as Table 1 in the Online Resource 1.

\section{D Explant Cultures}

The BTT samples were transported to the cell culture laboratory in cold $\left(+4{ }^{\circ} \mathrm{C}\right)$, sterile $0.9 \%$ sodium chloride $(\mathrm{NaCl})$ supplemented with penicillin $(100 \mathrm{IU} / \mathrm{mL})$, streptomycin $(100 \mu \mathrm{g} / \mathrm{mL})$ and Fungizone $(0,25 \mu \mathrm{g} / \mathrm{ml})$. The 3D explant cultures were established as previously described with some minor modifications [53-55]. Briefly, the tumour tissue was cut with surgical scalpel in tissue pieces of approximately $2 \times 2 \times 2 \mathrm{~mm}$ and the pieces were rinsed few times in Dulbecco's modified Eagle's medium/nutrient mixture F-12 (DMEM/F12) without phenol red (GIBCO, Paisley, UK), supplemented with penicillin $(100 \mathrm{IU} / \mathrm{ml})$, streptomycin $(100 \mu \mathrm{g} /$ $\mathrm{ml})$ and Fungizone $(0,25 \mu \mathrm{g} / \mathrm{ml})$. Thereafter, the tissue samples were transferred onto wet dental sponges (Spongostan ${ }^{\mathrm{TM}}$, Dental, Johnson \& Johnson) in 12-well plates and cultured for $24 \mathrm{~h}$ in phenol-red-free DMEM/F12 supplemented with $10 \%$ fetal bovine serum (FBS), penicillin $(100 \mathrm{IU} / \mathrm{mL})$, streptomycin $(100 \mu \mathrm{g} / \mathrm{mL})$, Fungizone $(0,25 \mu \mathrm{g} / \mathrm{ml}), 0.5 \mathrm{~mL}$ insulintransferrin-selenium (ITS supplement, Sigma, Germany) and $100 \mathrm{nM}$ hydrocortisone (Sigma). Schematic illustration of the 3D explant culture system is shown in Fig. 1. The explants

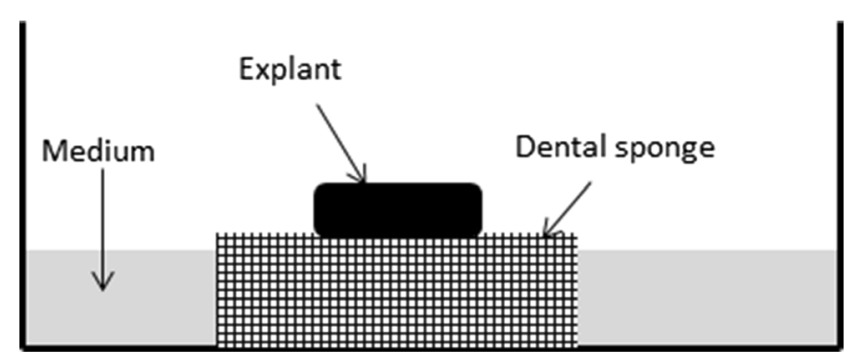

Fig. 1 Schematic illustration of the in vitro three-dimensional explant culture

were kept in a humidified atmosphere with a mixture of 5\% $\mathrm{CO}_{2}$ and $95 \%$ air at $+37{ }^{\circ} \mathrm{C}$. After $24 \mathrm{~h}$, the tumour explants were transduced as described below.

\section{Human Decorin cDNA Adenoviral Vector Transduction}

The 3D MBC explant cultures were transduced with a recombinant replication-deficient adenoviral vector carrying human decorin cDNA (Ad-DCN) as previously described [40] with minor modifications. $24 \mathrm{~h}$ after the $3 \mathrm{D}$ explant cultures were established, the medium in the wells was substituted with fresh one and the explants were transduced with 100 plaque forming units (pfu)/cell of Ad-DCN or control vector carrying human LacZ gene (Ad-LacZ). Tissue sections without transduction were used as negative controls. The viral vectors were pipetted on top of the tumour explants in a droplet of the culture medium. The amount of the viruses was estimated using established tissue size $2 \times 2 \times 2 \mathrm{~mm}$ and the mean breast carcinoma cell size [56] resulting in $2,5 \times 10^{4}$ cells in horizontal surface of the tissue section. In negative control cultures the medium was substituted with fresh one. After $24 \mathrm{~h}$, the medium in the wells was replaced with fresh one. Next day, tissue explants and dental sponges underneath them were fixed in $4 \%$ paraformaldehyde for $48 \mathrm{~h}$ at $+4{ }^{\circ} \mathrm{C}$ and embedded in paraffin. The paraffin blocks were cut into $4 \mu \mathrm{m}$ consecutive sections and stained for $\mathrm{HE}$ and $\mathrm{Ki}-67$ to evaluate the effect of Ad-DCN transduction on the cytology and the proliferation index of the explants.

\section{Visualization of HE and IHC, and Quantification of Ki-67}

All tissue sections were scanned with Pannoramic Digital Slide scanner (The Pannoramic 250 Flash, 3DHISTECH Ltd., Hungary). Digital images were viewed with Pannoramic Viewer (3DHISTECH). Nuclear staining $<1 \%$ of the tumour cells was considered negative for ER and PR. HER2 expression was evaluated as membrane staining of invasive tumour cells according to American Society of Clinical Oncology/ College of American Pathologists (ASCO/CAP) guidelines [57]. CK5/6 and EGFR with membranous and/or cytoplasmic staining were considered positive if at least $10 \%$ of the cancer cells showed staining. p63 and AR immunoreactions presented 
with strong nuclear staining. CD10 stained the cell membranes and the cytoplasm of the tumour cells. CK7, CkPan, GCDFP15, EMA and vimentin stained only the cytoplasm of the tumour cells. For the quantification of Ki-67 staining, 6 snapshots were taken from all stained samples and the quantification was performed with freely available ImmunoRatio software (http://153.1.200.58:8080/immunoratio/). The program automatically calculates the ratio of Ki-67 positive cells to total cell count.

\section{RNA Isolation and cDNA Synthesis}

Total RNA was extracted from the 3D MBC explant cultures using TRIsure RNA isolation reagent (Bioline, London, UK). To eliminate possible contaminating DNA, RNA samples were treated with 10 units of DNase I (Roche). cDNA was synthesized in a reaction using $1 \mu \mathrm{g}$ of total RNA and Sensifast cDNA Synthesis Kit (Bioline) according to the manufacturer's protocol.

\section{Quantitative Real-Time PCR}

Real-Time PCR (RT-qPCR) analyses of EGFR, ErbB2, ErbB3 and ErbB4 (JM-a) isoform expression was performed as previously described [58]. Expression of GAPDH was analysed as an internal control using primers 5'-AGCCACATCGCTCA GACAC-3', 5'-GCCCAATACGACCAAATCC-3' (Eurofins Genomics) and universal fluorescent probe \#60 (Universal ProbeLibrary, Roche). Thermal cycling was performed with QuantStudio 12 K Flex Real-Time PCR System (Thermo Fisher Scientific, MA, USA).

\section{Statistical Analysis}

The effect of Ad-DCN transduction on the proliferation index of the tissue explants was evaluated using Tukey's Multiple Comparison Test. The $p$ values $<0.05$ were considered statistically significant.

\section{Results}

\section{Pathological Findings}

Gross examination of the mastectomy specimen revealed a necrotic, cystic and haemorrhagic tumour mass measuring over $10 \mathrm{~cm}$ in diameter with poorly circumscribed infiltrative margins (Fig. 2). There was an extensive cutaneous ulceration with underlying dermal involvement by the tumour, but no fixation to the chest wall. The shortest surgical margin width was over $7 \mathrm{~mm}$. No lymphovascular invasion was observed during operation. However, postoperative pathological results revealed metastases in 2 lymph nodes out of 29 lymph nodes

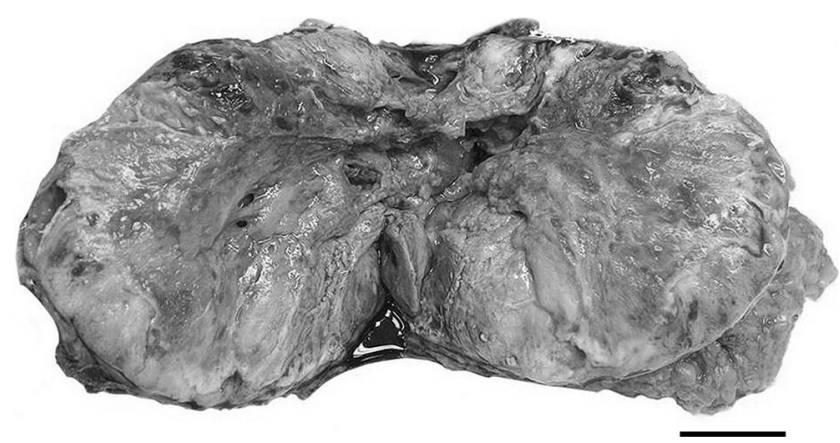

Fig. 2 Cut section of the massive necrotic breast tumour. Scale bar $5 \mathrm{~cm}$

in the right axilla. The largest lymph node metastasis was $12 \mathrm{~mm}$ in diameter. The general condition of the patient after the operation was satisfying. No further treatment after the surgery was planned because of her condition and old age. The patient died 6 months after the operation.

\section{Characterization of the Tumour}

The histopathology showed that the tumour was composed of intersection bundles of pleomorphic spindle shaped cells with large pleomorphic hyperchromatic nucleus and moderate amount of cytoplasm. There were also round to polygonal cells arranged in irregular sheets and occasional ductal structures. Apocrine differentiation was found focally with various clusters of papillary projections and sheets. In addition, a small, irregular lace-like osteoid was seen. Mitotic figures were numerous (data not shown).

The immunohistological profile of the tumour revealed a neoplasm with a highly heterogeneous histology. Selected IHC images are shown in Fig. 3. The epithelial (carcinomatous) component that showed focal and patchy configuration, stained positive for CkPan and CK7. Moderate cytoplasmic or membranous staining of $70 \%$ of epithelial component was positive for CK5/6. The epithelial component was accounted less than 1-2\% of the whole breast area. Mesenchymal component stained positive for vimentin and p63. Interestingly, some small areas of the tumour cells showed similar immunoreactivity for both CkPan and p63 (Fig. 3b and c). All tumour cells were ER, PR and HER2 negative. Ki-67 staining was positive in approximately $35 \%$ of the tumour cells. EGFR overexpression was assessed based on membrane staining, which showed strong intensity widely in the tumour area. In addition, CD10 positive cells were widely seen. There was also a sub-population of cells demonstrating apocrine differentiation by expressing AR, GCDFP-15 and EMA.

\section{Detection of Decorin and Biglycan in MBC Tissue}

Next we examined the immunoreactivity for two stromal PGs, namely $\mathrm{DCN}$ and BGN, in this MBC tumour. The results demonstrated that the tumour tissue was completely negative 


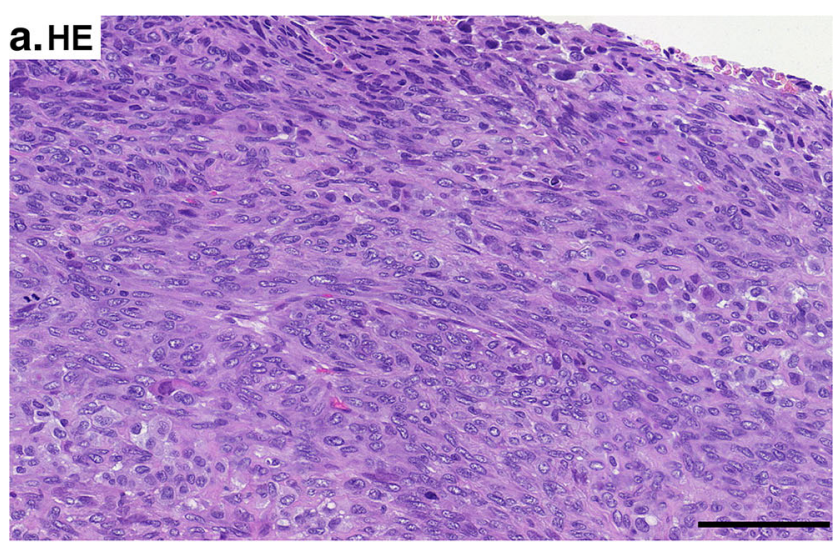

4 Fig. 3 Representative images of selected immunohistochemical stainings of the massive breast tumour. HE staining (a). Immunohistochemistry (IHC) for p63 (b). IHC for CkPan (c). IHC for Ki-67 (d). Positive immunoreactivity can be seen in brown. Scale bar $100 \mu \mathrm{m}$. Note that there are areas within the tumour showing immunoreactivity for both CkPan and p63 (3b and $\mathbf{c}$ ). This can be a display of carcinomatous epithelium transforming into metaplastic component

\section{Effects of Human Decorin cDNA Transduction on 3D MBC Explant Cultures}

Light microscopic observation of 3D MBC explant cultures revealed that Ad-DCN transduction resulted in a marked
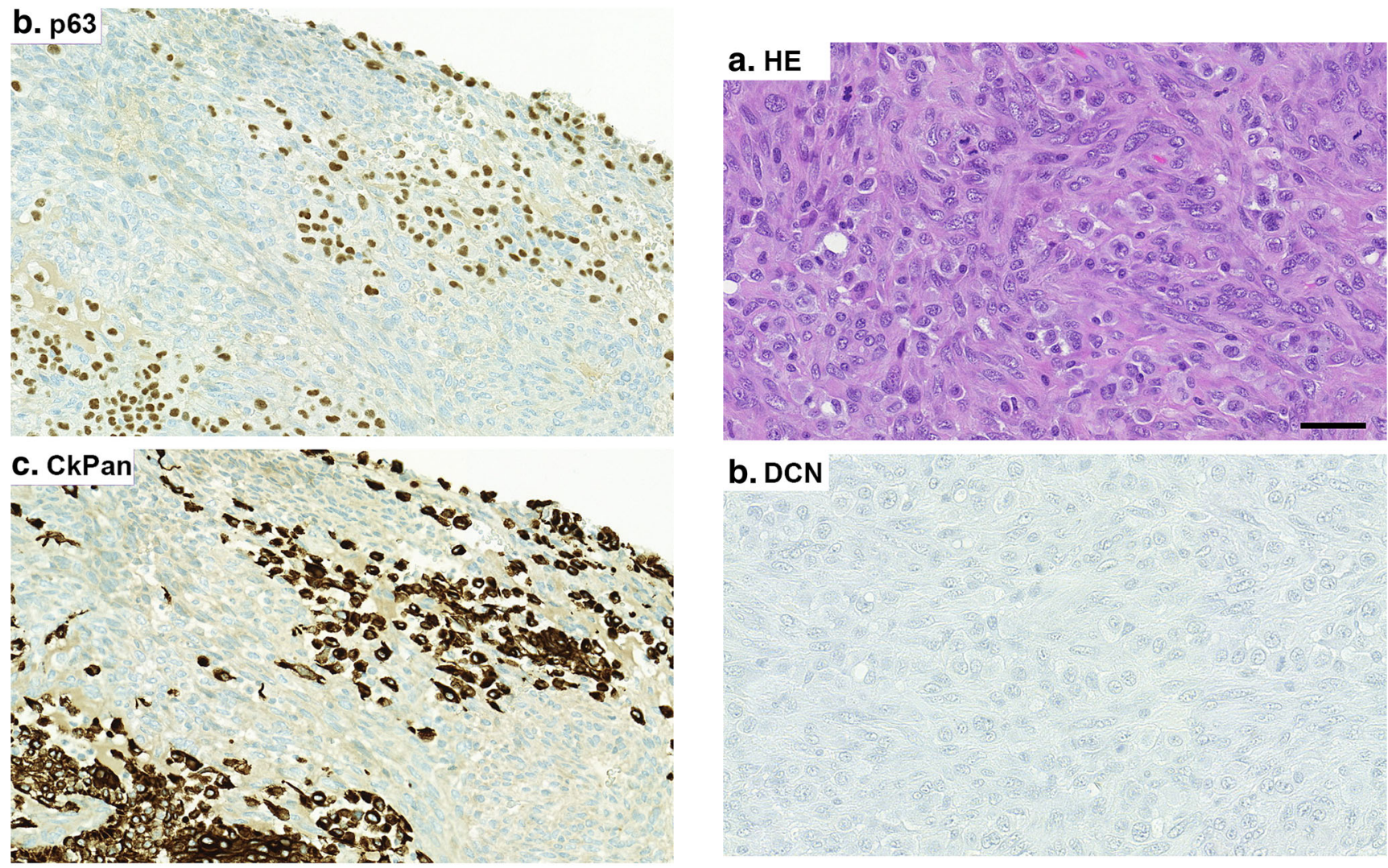

\section{b. DCN}

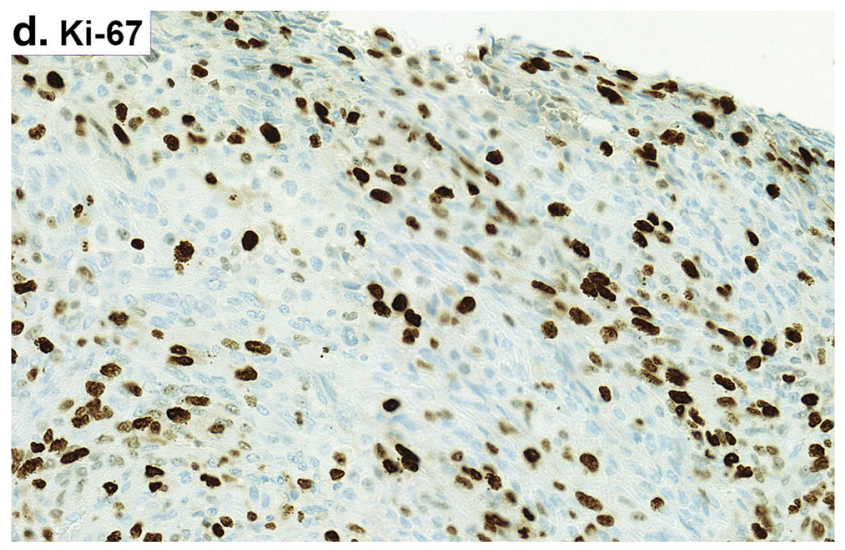

for DCN immunoreactivity, while BGN immunoreactivity was locally clearly detected (Fig. 4).

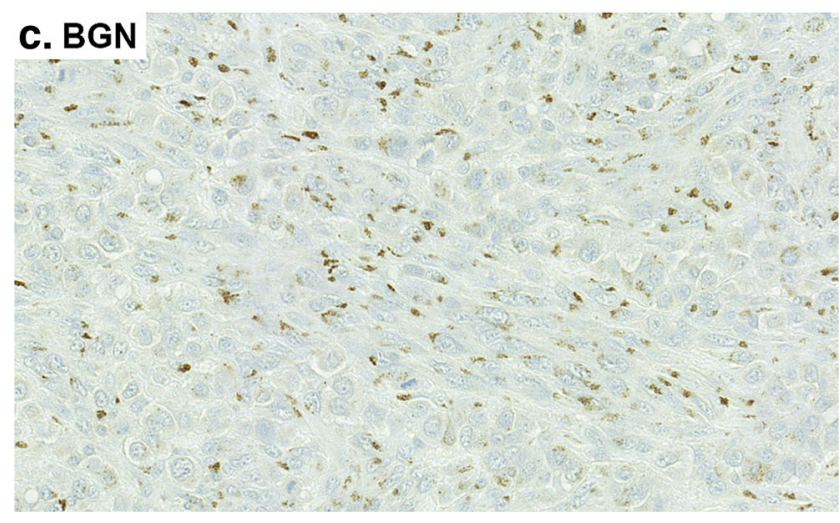

Fig. 4 Immunohistochemistry (IHC) for decorin (DCN) and biglycan (BGN) in MBC tissue. HE staining (a). IHC for DCN (b). IHC for BGN (c). Positive immunoreactivity can be seen in brown. Scale bar $50 \mu \mathrm{m}$. Note that the MBC tumour is completely negative for DCN immunoreactivity while immunoreactivity for BGN is clearly detected 
decrease in the cellularity and in the amount of atypical stromal cells compared to control vector (Ad-LacZ) transduced explants and to negative control cultures (Fig. 5). Explants after Ad-DCN transduction exhibited a lot of fibroblast-like cells in a more organized manner compared to explant cultures transduced with Ad-LacZ or to negative control cultures. Moreover, in Ad-DCN transduced explant cultures, residual rounded cancer cells with hyperchromatic nuclei were distributed in clusters and also areas of cell debris were clearly detected (Fig. 5a). There was also some cell debris present
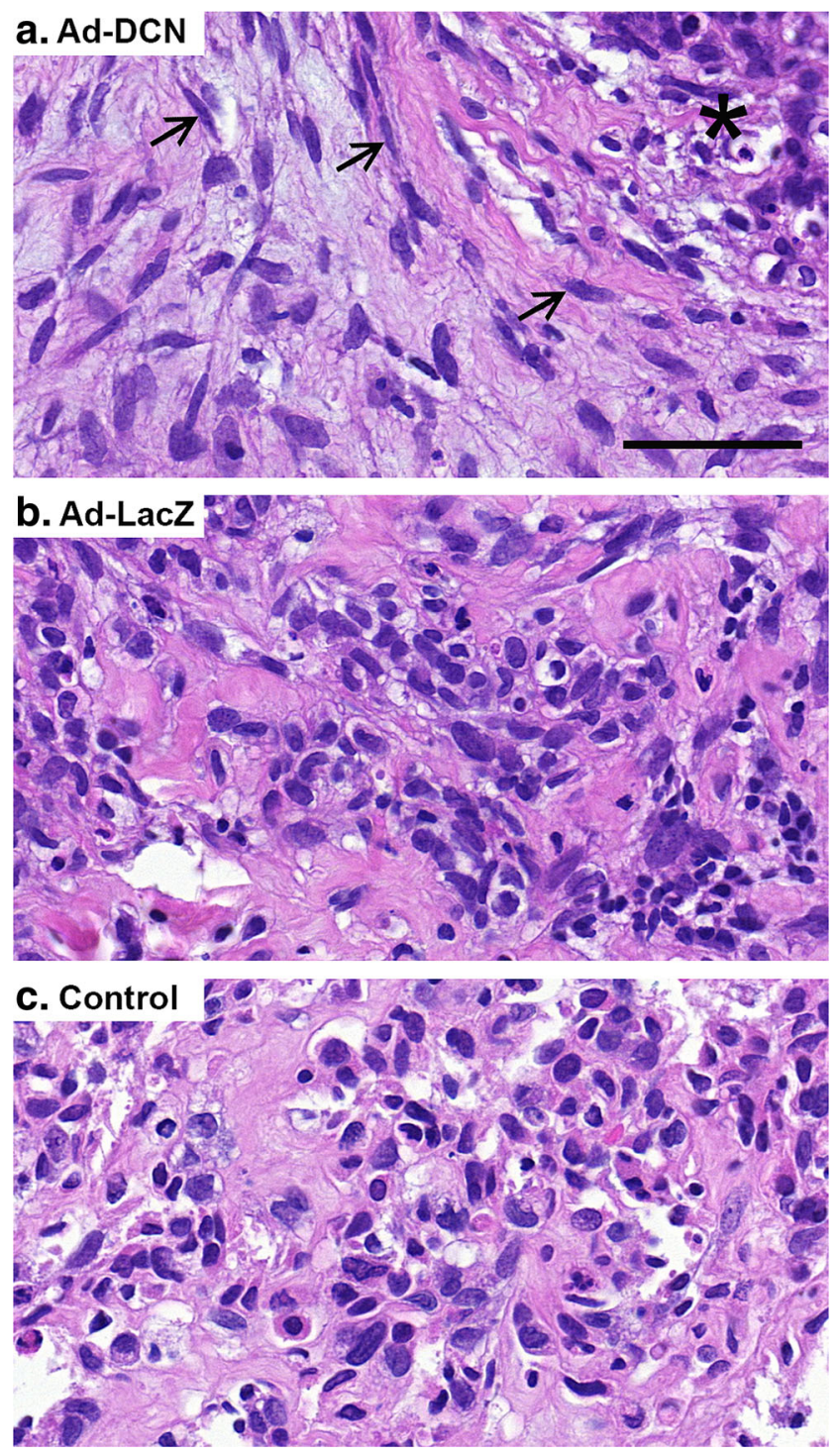

Fig. 5 Representative HE images of $M B C$ explant cultures after adenoviral transductions. Human decorin cDNA adenoviral transduction (Ad-DCN) (a). Adenoviral LacZ (vector control) transduction (Ad-LacZ) (b). Negative control explant (no viral transduction) (c). Note that Ad-DCN transduced explant cultures contain fibroblast-like cells (arrows) in a more organized manner compared to Ad-LacZ transduced explant cultures or to control cultures. Asterisk in image a indicates a representative area with cell debris and residual tumour cells. Scale bar $50 \mu \mathrm{m}$ in Ad-LacZ transduced explant cultures. Furthermore, a statistically significant decrease in the proliferation index (using Ki-67 staining) in Ad-DCN transduced explants compared to Ad-LacZ transduced explants or to control explants was observed (Fig. 6).

\section{Quantitation of mRNA Levels of ErbB Receptors}

The expression of the ErbB family members in the transduced BTT samples was studied with RT-qPCR. The results indicated that the MBC tissue expressed roughly similar levels of both EGFR and ErbB2 in all the samples; decorin cDNA and LacZ transduced, and negative controls (Fig. 1, Online Resource 2). No significant expression of ErbB3 or ErbB4 was detected.

\section{Discussion}

In this case report we first demonstrated using multiple immunostainings that the massive breast tumour exhibiting both epithelial and mesenchymal phenotypes was MBC. Next we showed that the tumour was completely negative for decorin immunoreactivity indicating that the cells that formed the MBC tumour were not able to synthesize decorin, a well-known oncosuppressive PG [32, 47]. Instead, there were locally abundant cancer cells that synthesized biglycan, a PG highly similar to decorin but with tumour-promoting function [48-51]. We have previously shown that decorin expression is lacking from Kaposi's sarcoma and angiosarcoma [52]. Quite recently we have also shown that human ductal, lobular and mucinous breast cancer cells lack decorin synthesis [40]. In all, our previous results together with the present study support the proposal that, mesenchymal and epithelial breast cancer cells are not able to synthesize decorin. Also our yet unpublished studies with testis-derived GTCs support the notion that decorin expression by cancer cells is predominantly absent. However, under certain circumstances some cancer cells, e.g. cancers of blastoma origin $[59,60]$ or osteosarcomas have been shown to be able to express decorin [61, 62]. Furthermore, proteomic approaches have revealed an association between metastasis and decorin expression in breast cancer [63]. However, it has to be considered that studies based on microarray and proteomic approaches utilizing tumour tissue samples consist not only of cancer cells but additionally of various other cells, e.g. cancer-associated fibroblasts and immune cells, in the TME [61, 63, 64]. Regarding the TME, many cancer types including breast cancer, exhibit phenomena called desmoplasia i.e., the accumulation of ECM macromolecules in the tumour vicinity, which may interfere the interpretation of the methods mentioned above [65-67].

In the present study we established 3D MBC explant cultures to examine whether Ad-DCN transduction might be able 


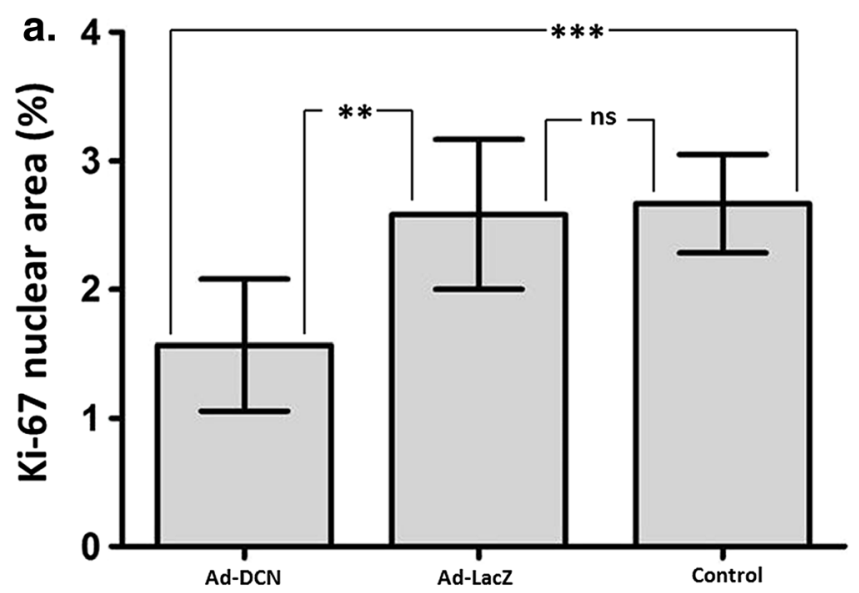

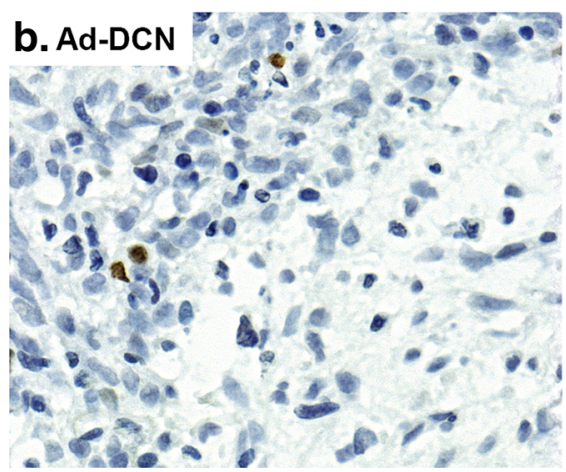

Fig. 6 Human decorin cDNA transduction of MBC explant cultures cause a statistically significant decrease in the proliferation index of the cells (using Ki-67). Histogram showing the results obtained from the ImmunoRatio software (a). Capped bars in the columns indicate SEMs,
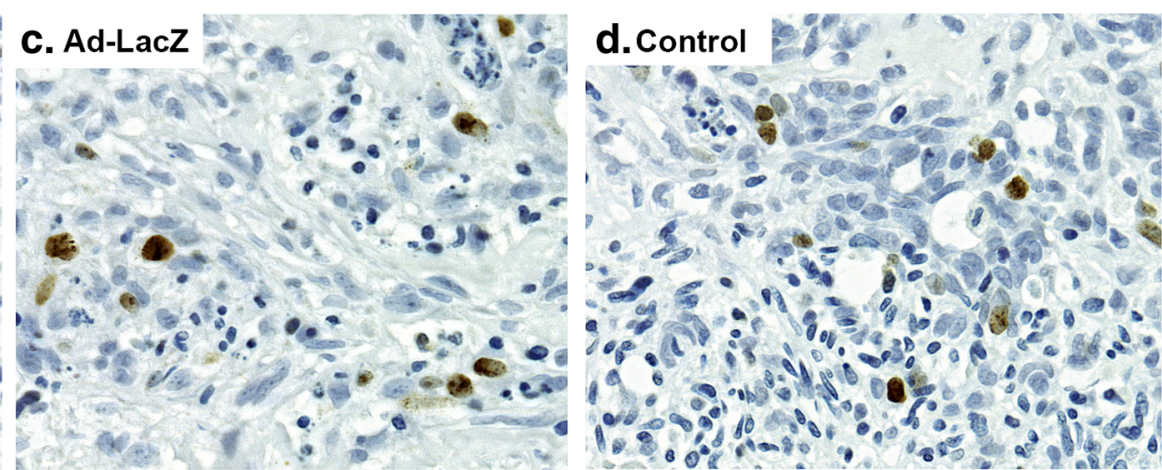

** $p<0.01 ; * * * p<0.001 ; \mathrm{ns}=$ non-significant. Representative images of explant cultures transduced with Ad-DCN (b) or Ad-LacZ (c), and without transduction (control, d). Ki-67 positive cells can be seen in brown. Scale bar $50 \mu \mathrm{m}$

adenoviruses [72]. For example, coxsackie and adenovirus receptor (CAR) has been identified for Ad5-based vectors, but its expression on different cancer cells can vary and also be downregulated as the cancer progresses [73]. Nevertheless, because the proliferation index is statistically significantly decreased in response to Ad-DCN transduction, it seems that the oncosuppressive effect of decorin cDNA adenoviral transduction applies not only to cancer cells of epithelial origin as we have shown earlier [40,74, 75], but also to malignant cells exhibiting mesenchymal phenotype. Previously decorin has been shown to be able to suppress also lung metastasis in osteosarcoma [76].

Decorin has also been shown to be able to modulate the signaling pathways of different growth factors such as EGF by binding to its receptors $[34,77]$. Particularly the activation of EGFR / ErbB1 and ErbB2 has been shown to be important in the progression of different human cancers, and decorin has been shown to interact with both of them [30, 33, 78, 79]. In this study, the relative expression of ErbB1-4 was examined in transduced BTT samples. The results showed that the MBC tissue expressed both EGFR and ErbB2, but the Ad-DCN transduction was not able to decrease their expression. This is likely due to the vast heterogeneity of the tumour tissue. transduction efficacy is subject to the cellular receptors for 
Furthermore, because the phosphorylation of the ErbB receptors was not examined, the ErbB pathway cannot be definitely excluded from the mechanisms whereby Ad-DCN transduction mediates its oncosuppressive function on MBC cells. In addition to ErbBs, decorin has also been shown to be able to regulate cell-matrix interactions via integrins $[80,81]$ and to induce apoptosis [82, 83]. Lately, the role of decorin in the regulation of cancer cell mitophagy has gained attention [84]. Furthermore, noteworthy is the idea of "normalization of the tumour microenvironment" whereby decorin in its part could orchestrate cancer cells towards a less malignant phenotype, and maybe even to a less malignant behaviour [85]. Indeed, the importance of decorin as a modifier of the TME in breast cancer has to be recognized $[86,87]$.

\section{Conclusions}

In this study we have examined decorin in human MBC. We have shown that MBC tissue that is a mixture of epithelial (carcinomatous) and mesenchymal (sarcomatous) elements, is negative for decorin immunoreactivity. The result indicates that the cells of MBC tissue are not able to synthesize this oncosuppressive small PG. We have also shown using 3D MBC explant cultures that decorin cDNA transduction alters the cytological features of the MBC tissue towards a less malignant phenotype. As MBCs form a rare and highly heterogeneous malignancy with poor prognosis due to fairly unsuccessful therapies currently available, novel adjuvant therapeutical approaches are required. The results of the present study favor the use of ECM macromolecules such as decorin in order to orchestrate, reengineer, reprogram, or normalize the structure and composition of the TME to achieve a less friendly environment for the cancer cells.

Acknowledgements The excellent technical assistance by Jaakko Liippo and Sinikka Collanus is highly appreciated.

\section{Compliance with Ethical Standards}

Conflict of Interest The authors declare that they have no conflict of interest.

Open Access This article is distributed under the terms of the Creative Commons Attribution 4.0 International License (http:// creativecommons.org/licenses/by/4.0/), which permits unrestricted use, distribution, and reproduction in any medium, provided you give appropriate credit to the original author(s) and the source, provide a link to the Creative Commons license, and indicate if changes were made.

\section{References}

1. Reis-Filho J, Lakhani S, Gobbi H, Sneige N (2012) Metaplastic carcinoma. WHO classification of tumours of the breast. In: Lakhani S, Ellis I, Schnitt S, Tan P, van der Vijver M (eds). Lyon, pp 34-38
2. Kang Y, Kang S, Li Q, Zheng X (2014) Mixed epithelial and mesenchymal metaplastic carcinoma (carcinosarcoma) of the breast: a case report. Eur J Med Res 19:14. doi:10.1186/2047-783X-19-14

3. Fernandez Perez MA, Viqueira Rodriguez I, Tello Royloa A, Martinez Guisasola J (2015) Metaplastic breast carcinoma with unusual presentation: review of three cases. Breast Care (Basel) 10:404-407

4. Geyer FC, Lambros MB, Natrajan R, Mehta R, Mackay A, Savage K, Parry S, Ashworth A, Badve S, Reis-Filho JS (2010) Genomic and immunohistochemical analysis of adenosquamous carcinoma of the breast. Mod Pathol 23:951-960

5. Shah DR, Tseng WH, Martinez SR (2012) Treatment options for metaplastic breast cancer. ISRN Oncol 2012:706162

6. Chen IC, Lin CH, Huang CS, Lien HC, Hsu C, Kuo WH, Lu YS, Cheng AL (2011) Lack of efficacy to systemic chemotherapy for treatment of metaplastic carcinoma of the breast in the modern era. Breast Cancer Res Treat 130:345-351

7. Song Y, Liu X, Zhang G, Song H, Ren Y, He X, Wang Y, Zhang J, Zhang Y, Sun S, Liang X, Sun Q, Pang D (2013) Unique clinicopathological features of metaplastic breast carcinoma compared with invasive ductal carcinoma and poor prognostic indicators. World J Surg Oncol 11:129

8. Chien T, Chou J, Chang T, Lin C (2010) Successful treatment of biphasic metaplastic sarcomatoid carcinoma of the breast by evaluation of immunohistochemical markers. Hematol Oncol Stem Cell Ther 3:89-93

9. Abouharb S, Moulder S (2015) Metaplastic breast cancer: clinical overview and molecular aberrations for potential targeted therapy. Curr Oncol Rep 17:10

10. Dieci MV, Orvieto E, Dominici M, Conte P, Guarneri V (2014) Rare breast cancer subtypes: histological, molecular, and clinical peculiarities. Oncologist 19:805-813

11. Rakha EA, Tan PH, Varga Z, Tse GM, Shaaban AM, Climent F, van Deurzen CH, Purnell D, Dodwell D, Chan T, Ellis IO (2015) Prognostic factors in metaplastic carcinoma of the breast: a multiinstitutional study. Br J Cancer 112:283-289

12. Hennessy BT, Gonzalez-Angulo AM, Stemke-Hale K, Gilcrease MZ, Krishnamurthy S, Lee JS, Fridlyand J, Sahin A, Agarwal R, Joy C, Liu W, Stivers D, Baggerly K, Carey M, Lluch A, Monteagudo C, He X, Weigman V, Fan C, Palazzo J, Hortobagyi GN, Nolden LK, Wang NJ, Valero V, Gray JW, Perou CM, Mills GB (2009) Characterization of a naturally occurring breast cancer subset enriched in epithelial-to-mesenchymal transition and stem cell characteristics. Cancer Res 69:4116-4124

13. Zhang Y, Toy KA, Kleer CG (2012) Metaplastic breast carcinomas are enriched in markers of tumor-initiating cells and epithelial to mesenchymal transition. Mod Pathol 25:178-184

14. Hanahan D, Weinberg RA (2000) The hallmarks of cancer. Cell 100:57-70

15. Werb Z, Lu P (2015) The role of stroma in tumor development. Cancer J 21:250-253

16. Hanahan D, Coussens LM (2012) Accessories to the crime: functions of cells recruited to the tumor microenvironment. Cancer Cell 21:309-322

17. Lu P, Weaver VM, Werb Z (2012) The extracellular matrix: a dynamic niche in cancer progression. J Cell Biol 196:395-406

18. Catalano V, Turdo A, Di Franco S, Dieli F, Todaro M, Stassi G (2013) Tumor and its microenvironment: a synergistic interplay. Semin Cancer Biol 23:522-532

19. Oskarsson T (2013) Extracellular matrix components in breast cancer progression and metastasis. Breast 22(Suppl 2):S66-S72

20. Theocharis AD, Skandalis SS, Neill T, Multhaupt HA, Hubo M, Frey H, Gopal S, Gomes A, Afratis N, Lim HC, Couchman JR, Filmus J, Sanderson RD, Schaefer L, Iozzo RV, Karamanos NK (2015) Insights into the key roles of proteoglycans in breast cancer 
biology and translational medicine. Biochim Biophys Acta 1855: 276-300

21. Theocharis AD, Skandalis SS, Gialeli C, Karamanos NK (2016) Extracellular matrix structure. Adv Drug Deliv Rev 97:4-27

22. Järveläinen H, Sainio A, Koulu M, Wight TN, Penttinen R (2009) Extracellular matrix molecules: potential targets in pharmacotherapy. Pharmacol Rev 61:198-223

23. Balkwill FR, Capasso M, Hagemann T (2012) The tumor microenvironment at a glance. J Cell Sci 125:5591-5596

24. Sainio A, Järveläinen H (2014) Extracellular matrix macromolecules: potential tools and targets in cancer gene therapy. Mol Cell Ther 2:14-8426-2-14. eCollection 2014

25. Hui L, Chen Y (2015) Tumor microenvironment: sanctuary of the devil. Cancer Lett 368:7-13

26. Cammarota F, Laukkanen MO (2016) Mesenchymal stem/stromal cells in stromal evolution and cancer progression. Stem Cells Int 2016:4824573

27. Afratis N, Gialeli C, Nikitovic D, Tsegenidis T, Karousou E, Theocharis AD, Pavao MS, Tzanakakis GN, Karamanos NK (2012) Glycosaminoglycans: key players in cancer cell biology and treatment. FEBS J 279:1177-1197

28. Nikitovic D, Kouvidi K, Voudouri K, Berdiaki A, Karousou E, Passi A, Tzanakakis GN (2014) The motile breast cancer phenotype roles of proteoglycans/glycosaminoglycans. Biomed Res Int 2014:124321

29. Schaefer L, Iozzo RV (2008) Biological functions of the small leucine-rich proteoglycans: from genetics to signal transduction. J Biol Chem 283:21305-21309

30. Iozzo RV, Moscatello DK, McQuillan DJ, Eichstetter I (1999) Decorin is a biological ligand for the epidermal growth factor receptor. J Biol Chem 274:4489-4492

31. Bi XL, Yang W (2013) Biological functions of decorin in cancer. Chin J Cancer 32:266-269

32. Järvinen TA, Prince S (2015) Decorin: a growth factor antagonist for tumor growth inhibition. Biomed Res Int 2015:654765

33. Santra M, Eichstetter I, Iozzo RV (2000) An anti-oncogenic role for decorin. Down-regulation of ErbB2 leads to growth suppression and cytodifferentiation of mammary carcinoma cells. J Biol Chem 275:35153-35161

34. Sofeu Feugaing DD, Götte M, Viola M (2013) More than matrix: the multifaceted role of decorin in cancer. Eur J Cell Biol 92:1-11

35. Horváth Z, Kovalszky I, Fullár A, Kiss K, Schaff Z, Iozzo RV, Baghy K (2014) Decorin deficiency promotes hepatic carcinogenesis. Matrix Biol 35:194-205

36. Bianco P, Fisher LW, Young MF, Termine JD, Robey PG (1990) Expression and localization of the two small proteoglycans biglycan and decorin in developing human skeletal and nonskeletal tissues. J Histochem Cytochem 38:1549-1563

37. Järveläinen HT, Kinsella MG, Wight TN, Sandell LJ (1991) Differential expression of small chondroitin/dermatan sulfate proteoglycans, PG-I/biglycan and PG-II/decorin, by vascular smooth muscle and endothelial cells in culture. J Biol Chem 266:23274 23281

38. Brown LF, Guidi AJ, Schnitt SJ, Van De Water L, Iruela-Arispe ML, Yeo TK, Tognazzi K, Dvorak HF (1999) Vascular stroma formation in carcinoma in situ, invasive carcinoma, and metastatic carcinoma of the breast. Clin Cancer Res 5:1041-1056

39. Leygue E, Snell L, Dotzlaw H, Troup S, Hiller-Hitchcock T, Murphy LC, Roughley PJ, Watson PH (2000) Lumican and decorin are differentially expressed in human breast carcinoma. J Pathol 192:313-320

40. Boström P, Sainio A, Kakko T, Savontaus M, Söderström M, Järveläinen H (2013) Localization of decorin gene expression in normal human breast tissue and in benign and malignant tumors of the human breast. Histochem Cell Biol 139:161-171
41. Bozoky B, Savchenko A, Guven H, Ponten F, Klein G, Szekely L (2014) Decreased decorin expression in the tumor microenvironment. Cancer Med 3:485-491

42. Troup S, Njue C, Kliewer EV, Parisien M, Roskelley C, Chakravarti S, Roughley PJ, Murphy LC, Watson PH (2003) Reduced expression of the small leucine-rich proteoglycans, lumican, and decorin is associated with poor outcome in node-negative invasive breast cancer. Clin Cancer Res 9:207-214

43. Li SJ, Chen DL, Zhang WB, Shen C, Che GW (2015) Prognostic value of stromal decorin expression in patients with breast cancer: a meta-analysis. J Thorac Dis 7:1939-1950

44. Araki K, Wakabayashi H, Shintani K, Morikawa J, Matsumine A, Kusuzaki K, Sudo A, Uchida A (2009) Decorin suppresses bone metastasis in a breast cancer cell line. Oncology 77:92-99

45. Yang Y, Xu W, Neill T, Hu Z, Wang CH, Xiao X, Stock SR, Guise T, Yun CO, Brendler CB, Iozzo RV, Seth P (2015) Systemic delivery of an oncolytic adenovirus expressing Decorin for the treatment of breast cancer bone metastases. Hum Gene Ther 26:813-825

46. Neill T, Schaefer L, Iozzo RV (2015) Oncosuppressive functions of decorin. Mol Cell Oncol 2:e975645

47. Neill T, Schaefer L, Iozzo RV (2016) Decorin as a multivalent therapeutic agent against cancer. Adv Drug Deliv Rev 97:174-185

48. Xing X, Gu X, Ma T, Ye H (2015) Biglycan up-regulated vascular endothelial growth factor (VEGF) expression and promoted angiogenesis in colon cancer. Tumour Biol 36:1773-1780

49. Maishi N, Ohba Y, Akiyama K, Ohga N, Hamada J, NagaoKitamoto H, Alam MT, Yamamoto K, Kawamoto T, Inoue N, Taketomi A, Shindoh M, Hida Y, Hida K (2016) Tumour endothelial cells in high metastatic tumours promote metastasis via epigenetic dysregulation of biglycan. Sci Rep 6:28039

50. Sun H, Wang X, Zhang Y, Che X, Liu Z, Zhang L, Qiu C, Lv Q, Jiang J (2016) Biglycan enhances the ability of migration and invasion in endometrial cancer. Arch Gynecol Obstet 293:429-438

51. Andrlova H, Mastroianni J, Madl J, Kern JS, Melchinger W, Dierbach H, Wernet F, Follo M, Technau-Hafsi K, Has C, Mittapalli VR, Idzko M, Herr R, Brummer T, Ungefroren H, Busch H, Boerries M, Narr A, Ihorst G, Vennin C, SchmittGraeff A, Minguet S, Timpson P, Duyster J, Meiss F, Romer W, Zeiser R (2017) Biglycan expression in the melanoma microenvironment promotes invasiveness via increased tissue stiffness inducing integrin-betal expression. Oncotarget. doi: 10.18632/oncotarget.17160

52. Salomäki HH, Sainio AO, Söderström M, Pakkanen S, Laine J, Järveläinen HT (2008) Differential expression of decorin by human malignant and benign vascular tumors. J Histochem Cytochem 56: 639-646

53. Zhuang YH, Saaristo R, Ylikomi T (2003) An in vitro long-term culture model for normal human mammary gland: expression and regulation of steroid receptors. Cell Tissue Res 311:217-226

54. Eigèlienè N, Härkönen P, Erkkola R (2006) Effects of estradiol and medroxyprogesterone acetate on morphology, proliferation and apoptosis of human breast tissue in organ cultures. BMC Cancer 6:246

55. Dean JL, McClendon AK, Hickey TE, Butler LM, Tilley WD, Witkiewicz AK, Knudsen ES (2012) Therapeutic response to CDK4/6 inhibition in breast cancer defined by ex vivo analyses of human tumors. Cell Cycle 11:2756-2761

56. Sastre-Garau X, Genin P, Rousseau A, Al Ghuzlan A, Nicolas A, Freneaux P, Rosty C, Sigal-Zafrani B, Couturier J, Thiery JP, Magdelenat H, Vincent-Salomon A (2004) Increased cell size and Akt activation in HER-2/neu-overexpressing invasive ductal carcinoma of the breast. Histopathology 45:142-147

57. Wolff AC, Hammond ME, Hicks DG, Dowsett M, McShane LM, Allison KH, Allred DC, Bartlett JM, Bilous M, Fitzgibbons P, Hanna W, Jenkins RB, Mangu PB, Paik S, Perez EA, Press MF, Spears PA, Vance GH, Viale G, Hayes DF, American Society of Clinical Oncology, College of American Pathologists (2013) 
Recommendations for human epidermal growth factor receptor 2 testing in breast cancer: American Society of Clinical Oncology/ College of American Pathologists clinical practice guideline update. J Clin Oncol 31:3997-4013

58. Junttila TT, Laato M, Vahlberg T, Soderstrom KO, Visakorpi T, Isola J, Elenius K (2003) Identification of patients with transitional cell carcinoma of the bladder overexpressing ErbB2, ErbB3, or specific ErbB4 isoforms: real-time reverse transcription-PCR analysis in estimation of ErbB receptor status from cancer patients. Clin Cancer Res 9:5346-5357

59. Santra M, Katakowski M, Zhang RL, Zhang ZG, Meng H, Jiang F, Chopp M (2006) Protection of adult mouse progenitor cells and human glioma cells by de novo decorin expression in an oxygenand glucose-deprived cell culture model system. J Cereb Blood Flow Metab 26:1311-1322

60. Farace C, Oliver JA, Melguizo C, Alvarez P, Bandiera P, Rama AR, Malaguarnera G, Ortiz R, Madeddu R, Prados J (2015) Microenvironmental modulation of Decorin and Lumican in Temozolomide-resistant glioblastoma and neuroblastoma cancer stem-like cells. PLoS One 10:e0134111

61. Kubista B, Klinglmueller F, Bilban M, Pfeiffer M, Lass R, Giurea A, Funovics PT, Toma C, Dominkus M, Kotz R, Thalhammer T, Trieb K, Zettl T, Singer CF (2011) Microarray analysis identifies distinct gene expression profiles associated with histological subtype in human osteosarcoma. Int Orthop 35:401-411

62. Zafiropoulos A, Nikitovic D, Katonis P, Tsatsakis A, Karamanos NK, Tzanakakis GN (2008) Decorin-induced growth inhibition is overcome through protracted expression and activation of epidermal growth factor receptors in osteosarcoma cells. Mol Cancer Res 6:785-794

63. Cawthorn TR, Moreno JC, Dharsee M, Tran-Thanh D, Ackloo S, Zhu PH, Sardana G, Chen J, Kupchak P, Jacks LM, Miller NA, Youngson BJ, Iakovlev V, Guidos CJ, Vallis KA, Evans KR, McCready D, Leong WL, Done SJ (2012) Proteomic analyses reveal high expression of decorin and endoplasmin (HSP90B1) are associated with breast cancer metastasis and decreased survival. PLoS One 7:e30992

64. Lu P, Takai K, Weaver VM, Werb Z (2011) Extracellular matrix degradation and remodeling in development and disease. Cold Spring Harb Perspect Biol 3:a005058

65. Walker RA (2001) The complexities of breast cancer desmoplasia. Breast Cancer Res 3:143-145

66. Sainio A, Järveläinen H (2013) Extracellular matrix macromolecules in tumour microenvironment with special reference to desmoplastic reaction and the role of matrix proteoglycans and Hyaluronan. J Carcinog Mutagen. doi:10.4172/2157-2518.S13-002

67. Kaushik S, Pickup MW, Weaver VM (2016) From transformation to metastasis: deconstructing the extracellular matrix in breast cancer. Cancer Metastasis Rev 35:655-667

68. Bi X, Pohl NM, Qian Z, Yang GR, Gou Y, Guzman G, KajdacsyBalla A, Iozzo RV, Yang W (2012) Decorin-mediated inhibition of colorectal cancer growth and migration is associated with Ecadherin in vitro and in mice. Carcinogenesis 33:326-330

69. Xu Y, Xia Q, Rao Q, Shi S, Shi Q, Ma H, Lu Z, Chen H, Zhou X (2016) DCN deficiency promotes renal cell carcinoma growth and metastasis through downregulation of P21 and E-cadherin. Tumour Biol 37:5171-5183

70. Liu Z, Yang Y, Zhang X, Wang H, Xu W, Wang H, Xiao F, Bai Z, Yao H, Ma X, Jin L, Wu CT, Seth P, Zhang Z, Wang L (2017) An oncolytic adenovirus encoding decorin and GM-CSF inhibits tumor growth in a colorectal tumor model by targeting pro-tumorigenic signals and via immune-activation. Hum Gene Ther. doi:10.1089/ hum.2017.033

71. Mak KY, Rajapaksha IG, Angus PW, Herath CB (2017) The adenoassociated virus - a safe and effective vehicle for liver-specific Gene therapy of inherited and non-inherited diseases. Curr Gene Ther. doi:10.2174/1566523217666170314141931

72. Arnberg N (2012) Adenovirus receptors: implications for targeting of viral vectors. Trends Pharmacol Sci 33:442-448

73. Sasaki T, Tazawa H, Hasei J, Osaki S, Kunisada T, Yoshida A, Hashimoto Y, Yano S, Yoshida R, Kagawa S, Uno F, Urata Y, Ozaki T, Fujiwara T (2013) A simple detection system for adenovirus receptor expression using a telomerase-specific replicationcompetent adenovirus. Gene Ther 20:112-118

74. Sainio A, Nyman M, Lund R, Vuorikoski S, Boström P, Laato M, Boström PJ, Järveläinen H (2013) Lack of decorin expression by human bladder cancer cells offers new tools in the therapy of urothelial malignancies. PLoS One 8:e76190

75. Nyman MC, Sainio AO, Pennanen MM, Lund RJ, Vuorikoski S, Sundström JT, Järveläinen HT (2015) Decorin in human Colon cancer: localization in vivo and effect on cancer cell behavior in vitro. J Histochem Cytochem 63:710-720

76. Shintani K, Matsumine A, Kusuzaki K, Morikawa J, Matsubara T, Wakabayashi T, Araki K, Satonaka H, Wakabayashi H, Iino T, Uchida A (2008) Decorin suppresses lung metastases of murine osteosarcoma. Oncol Rep 19:1533-1539

77. Zhu JX, Goldoni S, Bix G, Owens RT, McQuillan DJ, Reed CC, Iozzo RV (2005) Decorin evokes protracted internalization and degradation of the epidermal growth factor receptor via caveolar endocytosis. J Biol Chem 280:32468-32479

78. Goldoni S, Seidler DG, Heath J, Fassan M, Baffa R, Thakur ML, Owens RT, McQuillan DJ, Iozzo RV (2008) An antimetastatic role for decorin in breast cancer. Am J Pathol 173:844-855

79. Dhomen NS, Mariadason J, Tebbutt N, Scott AM (2012) Therapeutic targeting of the epidermal growth factor receptor in human cancer. Crit Rev Oncog 17:31-50

80. Fiedler LR, Schönherr E, Waddington R, Niland S, Seidler DG, Aeschlimann D, Eble JA (2008) Decorin regulates endothelial cell motility on collagen I through activation of insulin-like growth factor I receptor and modulation of alpha2beta1 integrin activity. J Biol Chem 283:17406-17415

81. Jungmann O, Nikolovska K, Stock C, Schulz JN, Eckes B, Riethmuller C, Owens RT, Iozzo RV, Seidler DG (2012) The dermatan sulfate proteoglycan decorin modulates alpha2beta1 integrin and the vimentin intermediate filament system during collagen synthesis. PLoS One 7:e50809

82. Dimmeler S, Zeiher AM (2000) Endothelial cell apoptosis in angiogenesis and vessel regression. Circ Res 87:434-439

83. Järveläinen H, Sainio A, Wight TN (2015) Pivotal role for decorin in angiogenesis. Matrix Biol 43:15-26

84. Neill T, Torres A, Buraschi S, Owens RT, Hoek JB, Baffa R, Iozzo RV (2014) Decorin induces mitophagy in breast carcinoma cells via peroxisome proliferator-activated receptor gamma coactivator1alpha (PGC-1alpha) and mitostatin. J Biol Chem 289:4952-4968

85. Whatcott CJ, Han H, Von Hoff DD (2015) Orchestrating the tumor microenvironment to improve survival for patients with pancreatic cancer: normalization, not destruction. Cancer J 21:299-306

86. Pickup MW, Mouw JK, Weaver VM (2014) The extracellular matrix modulates the hallmarks of cancer. EMBO Rep 15:1243-1253

87. Insua-Rodriguez J, Oskarsson T (2016) The extracellular matrix in breast cancer. Adv Drug Deliv Rev 97:41-55 